\title{
Demographic Factors in the Evaluation of Service Quality in Higher Education: A Structural Equation Model (SEM) Approach
}

\author{
Sein $\operatorname{Min}^{1} \&$ Chey Chor Khoon ${ }^{2}$ \\ ${ }^{1}$ MDIS Business School, Singapore \\ ${ }^{2}$ Nanyang Technological University, Singapore \\ Correspondence: Sein Min, MDIS Business School, Singapore. E-mail: sein_min@mdis.edu.sg
}

Received: July 29, 2013 Accepted: September 13, $2013 \quad$ Online Published: January 22, 2014

doi:10.5539/ijms.v6n1p90 URL: http://dx.doi.org/10.5539/ijms.v6n1p90

\begin{abstract}
The increasing number of international students studying in advanced countries has sparked attention on service quality in higher education. Perception of service quality is subjective, and is believed to vary with the demographic characteristics of students. This study attempts to investigate the role that demographic factors play in service quality evaluation in the higher education sector. The framework used in this study is adopted from Min, Khoon and Tan (2012) and consists of four key constructs, namely motivation, expectation, perception and satisfaction. Applying the Structural Equation Model (SEM) approach to data collected from a sample of 263 international students in a private higher education institution in Singapore, the present study found that motive of study has moderate relationship with expectation and perception of service quality. Satisfaction of students is also closely and significantly related with the perception of service quality. It was also found that demography impacted on the relationships between the elements of service quality. The study included four demographic variables (gender, age, nationality and current level of study) and it was found that nationality and gender have considerable impact on the weights of relationships. The research findings suggest that education marketers should take demographic factors into consideration in the design and development of education services.
\end{abstract}

Keywords: service quality, motives, expectation, perception, satisfaction, demographic factor, higher education

\section{Introduction}

\subsection{Research Problem}

Increasing globalization and the consequent changing environment have impacted higher education around the world by, for example, increasing the mobility of students and the internationalization of education institutions (Arambewela \& Hall, 2006). In efforts to attract more international students, universities and colleges are adopting the marketing concept whereby students are considered as customers. They are also paying closer attention towards service quality. The long-term survival of universities and colleges depends on the degree to which service quality meets their students' expectations (Tsinidou, Gerogiannis, \& Fitisilis, 2010).

Service quality in higher education has been studied by many scholars, e.g., Adee (1997), Ham and Hayduck (2003), Arambewela and Hall (2006), Barnes (2007), Ilias, Harson, Rahman and Yasoa (2008). Although the influence of demographic factors has been examined in various contexts and purposes, there appears to be a significant gap in the literature on how demographic factors affect the way international students evaluate service quality. One important demographic factor is "nationality". It is important to establish whether students from different countries have similar ways of perceiving and evaluating service quality. Similarly, other demographic variables such as age, gender, level of study and so forth can play a role in the process of evaluation of service quality. In brief, the role that demographic factors play in impacting on the expectation and perception of service quality is a critical area of investigation.

Thus, this research is to find out the moderating role of demographic factors in the process of motivation, expectation, perception and satisfaction of international students pursuing higher education in Singapore.

\subsection{Literature Review}

Many studies have tried to establish the impact that consumers' demographic factors may have on their perception of service quality across a wide range of services such as retailing (Gagliano \& Hathcoste, 1994), 
health care (Al-Khalil \& Mahmoud, 2012), banking (Ramez, 2011; Gupta \& Bansal, 2011), transport services (Ganesan-Lim et al., 2008), telecommunication (Chih, Tang, \& Chen, n.d.) etc. While some researchers conclude that service quality is perceived differently by consumers according to their demographic backgrounds, there are also findings that do not confirm the crucial role of demographic factors. For example, Ramez (2011) found that demographic variables did not significantly account for differences in the perception of service quality of Bahraini commercial banks.

Schwantz (1996)'s research considered only the age factor, dividing it into two categories, below 25 years old ("traditional" students) and above 25 years old ("non-traditional" students), as the aim was to explore the differences in service experiences between the regular, traditional students and working, adult students. This study could not find a significant difference between these two groups, contradicting the view by Parasuraman, Berry and Zeithaml (1991) that more experienced customers expected higher service quality.

Jusoh et al. (2004) studied the factors influencing service quality in higher education, namely seniority, course, cultural (race), gender and academic (CPA). Their analysis showed that perception of service quality differed significantly by year of study and race. However, the study did not find any significant relationship between students' academic performance and service quality.

Ilias et al. (2008) studying bachelor degree students in private higher education institutions could not find any significant differences in demographic variables in the perception of service quality of higher education. The authors recognized contradictions in the research findings of previous studies. For instance, Soutar and McNeil (1994) found that there was a significant relationship between gender and satisfaction with service quality, while Joseph (1998) and Ham and Hayduk (2003) found that gender had no significant relationship with perceived service quality (cited by Ilias et al., 2008).

Palli and Mamilla (2012) found mixed results in their study of higher education institutions, particularly S. V. University. Their findings indicated no significant difference in the overall satisfaction of the respondents in terms of age, occupation of the parent, and total household income, but there were significant differences in the students' opinions based on gender. For example, female respondents were more satisfied than male respondents with regard to the service quality of departments of the university. Such mixed results can be also seen in the transport/travel service sector. Genesan-Lim et al. (2008) found that age was the significant factor in the perception of service quality of passenger transport services, but gender and income were not found to be significant.

Table 1. Summary of research findings of demographics' impact on perception of service quality in selected service areas

\begin{tabular}{|c|c|c|c|c|c|}
\hline & Service Area & Author(s) & $\begin{array}{l}\text { Major Demographic } \\
\text { Variables }\end{array}$ & $\begin{array}{l}\text { Service Quality } \\
\text { Model }\end{array}$ & Findings \\
\hline 1 & Retailing & $\begin{array}{l}\text { Gagliano \& Hathcoste } \\
\text { (1994) }\end{array}$ & $\begin{array}{l}\text { Race, Marital } \\
\text { Status, Income }\end{array}$ & SERVQUAL & $\begin{array}{l}\text { Consumer demographic characteristics of race, } \\
\text { marital status, and income provided significant } \\
\text { differences between expectations and perceptions } \\
\text { for Reliability and Convenience. }\end{array}$ \\
\hline 2 & Health care & $\begin{array}{l}\text { Al-Khalil \& Mahmoud } \\
\text { (2012) }\end{array}$ & $\begin{array}{l}\text { Gender, Education, } \\
\text { Age, Income }\end{array}$ & $\begin{array}{l}20 \text {-item } \\
\text { multidimensional } \\
\text { scale }\end{array}$ & $\begin{array}{l}\text { Lower educated female patients could hold less } \\
\text { perceived service quality for health care services } \\
\text { than other categories of patients. }\end{array}$ \\
\hline \multirow[t]{4}{*}{3} & $\begin{array}{l}\text { (Higher) } \\
\text { Education }\end{array}$ & Schwantz (1996) & $\begin{array}{l}\text { Traditional (age } 24 \\
\text { and below) and } \\
\text { non-traditional (age } \\
25 \text { and above) }\end{array}$ & SERVQUAL & $\begin{array}{l}\text { There was no significant difference in } \\
\text { expectations of service quality between traditional } \\
\text { and non-traditional undergraduate students. }\end{array}$ \\
\hline & & Jusoh, et al. (2004) & Seniority, Gender & SERVPERF & $\begin{array}{l}\text { There are significant differences based on the } \\
\text { students' perception of this faculty service quality } \\
\text { by year of study and race. }\end{array}$ \\
\hline & & Ilias, et al. (2008) & $\begin{array}{l}\text { Gender, Race and } \\
\text { Semester of Study }\end{array}$ & SERVQUAL & $\begin{array}{l}\text { Demographic factors (gender, semester of studies, } \\
\text { ethnicity) do not have any significant impact on } \\
\text { service quality. }\end{array}$ \\
\hline & & $\begin{array}{l}\text { Palli \& Mamilla } \\
\text { (2012) }\end{array}$ & $\begin{array}{l}\text { Gender, Age group, } \\
\text { Course of study, } \\
\text { Marital Status, } \\
\text { Academic Year, } \\
\text { Occupation of the } \\
\text { parent, Income of } \\
\text { household }\end{array}$ & $\begin{array}{l}\text { SERVQUAL and } \\
\text { Authors'own } \\
\text { conceptual } \\
\text { framework }\end{array}$ & $\begin{array}{l}\text { The results indicated no significant difference in } \\
\text { the overall satisfaction of the respondents in terms } \\
\text { of age, occupation of the parent and total } \\
\text { household income. Significant difference in the } \\
\text { overall satisfaction of the respondents was found } \\
\text { only in terms of gender. }\end{array}$ \\
\hline
\end{tabular}




\begin{tabular}{|c|c|c|c|c|c|}
\hline \multirow[t]{2}{*}{4} & Banking & Ramez (2011) & $\begin{array}{l}\text { Gender, Age, } \\
\text { Education, } \\
\text { Nationality, } \\
\text { Occupation }\end{array}$ & SERVQUAL & $\begin{array}{l}\text { There are no significant differences in gender, age, } \\
\text { education level and nationality groups the } \\
\text { perception of the overall service quality and its } \\
\text { five dimensions. }\end{array}$ \\
\hline & & $\begin{array}{l}\text { Gupta \& Bansal } \\
\text { (2011) }\end{array}$ & $\begin{array}{l}\text { Gender, Age, } \\
\text { Occupation, } \\
\text { Education and } \\
\text { Income }\end{array}$ & $\begin{array}{l}\text { 22-items of Internet } \\
\text { banking service } \\
\text { quality developed } \\
\text { by authors }\end{array}$ & $\begin{array}{l}\text { Gender, age, occupation, education level, and } \\
\text { income rated differently the dimensions of service } \\
\text { quality of banks. }\end{array}$ \\
\hline 5 & $\begin{array}{l}\text { Transport / } \\
\text { Travel } \\
\text { services }\end{array}$ & $\begin{array}{l}\text { (Ganesan-Lim, et al. } \\
\text { (2008) }\end{array}$ & $\begin{array}{l}\text { Age, Gender and } \\
\text { Income }\end{array}$ & $\begin{array}{l}\text { Interaction quality, } \\
\text { outcome quality } \\
\text { and physical } \\
\text { environment quality } \\
\text { (Brady \& Cronin, } \\
\text { 2001) }\end{array}$ & $\begin{array}{l}\text { Consumer age was found to affect service quality } \\
\text { perception. However, no differences in the service } \\
\text { quality perceptions on the basis of quality, } \\
\text { perceptions on the basis of gender or income were } \\
\text { found. }\end{array}$ \\
\hline 6 & $\begin{array}{l}\text { Telecommuni } \\
\text { ca-tion }\end{array}$ & Chih, et al. (n.d.) & $\begin{array}{l}\text { Gender, Age, } \\
\text { Education, } \\
\text { Occupation, } \\
\text { Disposable Income }\end{array}$ & $\begin{array}{l}\text { Modified } \\
\text { SERVQUAL }\end{array}$ & $\begin{array}{l}\text { Significant differences exist in service quality } \\
\text { perception across lifestyle and demographic } \\
\text { variables. }\end{array}$ \\
\hline
\end{tabular}

\subsection{Hypotheses}

The primary hypothesis of this research is:

Demographic factors of international students do not influence on the evaluation of service quality of higher education institutions

In this study, four key demographic variables, namely gender, age, nationality and level of study (master, bachelor and diploma), are considered and their influences on the evaluation of service quality are investigated. The secondary hypotheses are formulated as:

H1: Gender of international students does not influence on the process of service quality evaluation.

H2: Age of international students does not influence on the process of service quality evaluation.

H3: Nationality of international students does not influence on the process of service quality evaluation.

H4: Level of study of international students does not influence on the process of service quality evaluation.

\section{Method}

\subsection{Conceptual Framework}

Service quality of a business is measured usually by the expectation and actual perception of service by its customers. Schiffman and Kanuk (2007) stated that "The most widely accepted framework for researching service quality stems from the premise that a consumer's evaluation of service quality is a function of the magnitude and direction of the gap between customer's expectations of service and the customer's assessment (perception) of the service actually delivered" (p. 177). According to Parasuraman et al. (1985), service quality is to be analysed in five gaps between the stages along the service delivery process: consumer expectation, management perception, service quality specification, service delivery, external communication and perceived service. In fact, the SERVQUAL model by Parasuraman, Ziethaml and Berry (1998) focuses specifically on the Gap 5 of the original service quality model and adopts five service dimensions, namely reliability, assurance, tangibility, empathy and responsiveness (Parasuraman, Zeithaml, \& Berry, 1988; Buttle, 1996).

In this study, service quality of higher education is measured and analysed by the service quality framework proposed and applied by Min, Khoon and Tan (2012) which is basically the SERVQUAL model and applies the same five service dimensions. However, it measures the service dimensions in the setting of higher education and for the international students. The model incorporates also the students' motives of study and satisfaction on educational services received. The basic features of the model are depicted in Figure 1. 
MOTIVES

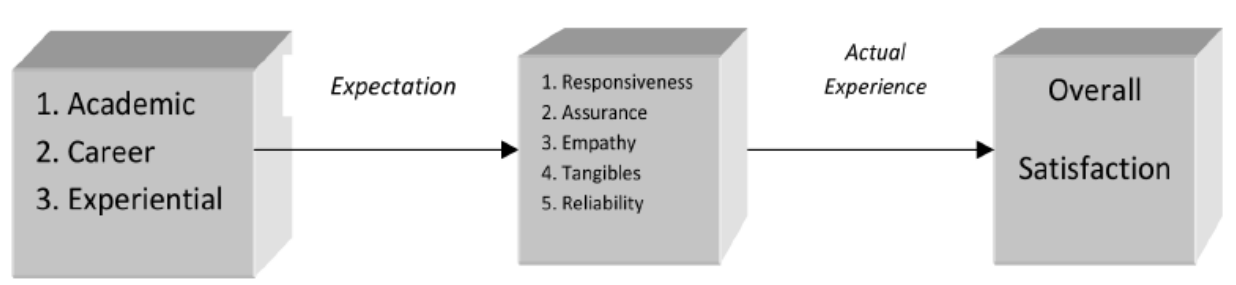

Figure 1. Simplified model of service process in higher education (Min et al., 2012, p. 126)

Based on the literature on international students, Min et al. (2012) identified three basic motives held by international students: academic, career and experiential.

Academic (seeking purely high quality, high standard education with recognition from employers, quality teaching, hardworking in their academic pursuits)

- Career (seeking opportunities to get a job, now or later, attracted by job market conditions in the host country, aiming to settle down in the host country, i.e. migration)

- Experiential (putting high value on the experience of staying abroad, particularly the host country of study, looking for opportunities to actively participate in social and cultural events, expecting to meet with people from different countries, learning the international culture and host country's culture)

Min, et al. (2012) discovered from their empirical study an additional motive of students, namely 'work'.

- Work (aiming to earn money and / or to gain work experience during the course of study)

The measurement of expectations and perceptions (actual experience) applies the same sub-dimensions (statements) to be rated on a 5-point Likert scale. Similarly overall satisfaction is measured by a number of statements that are rated using 5-point Likert scale too.

For the present study, the model by Min et al. (2012) is extended by adding the new element, namely demographic variables of respondents. As seen in the literature review, demographic variables can influence the evaluation of service quality and customer satisfaction, in spite of the fact that there is no unified effect and degree of influence. Thus, we intend to investigate the influence of demographic factors on the international students' perception of service quality in higher education. Demographic variables are incorporated into the basic model of service process by Min et al. (2012) as shown in Figure 2. The demographic variables included are age, gender, nationality, and level of study. 


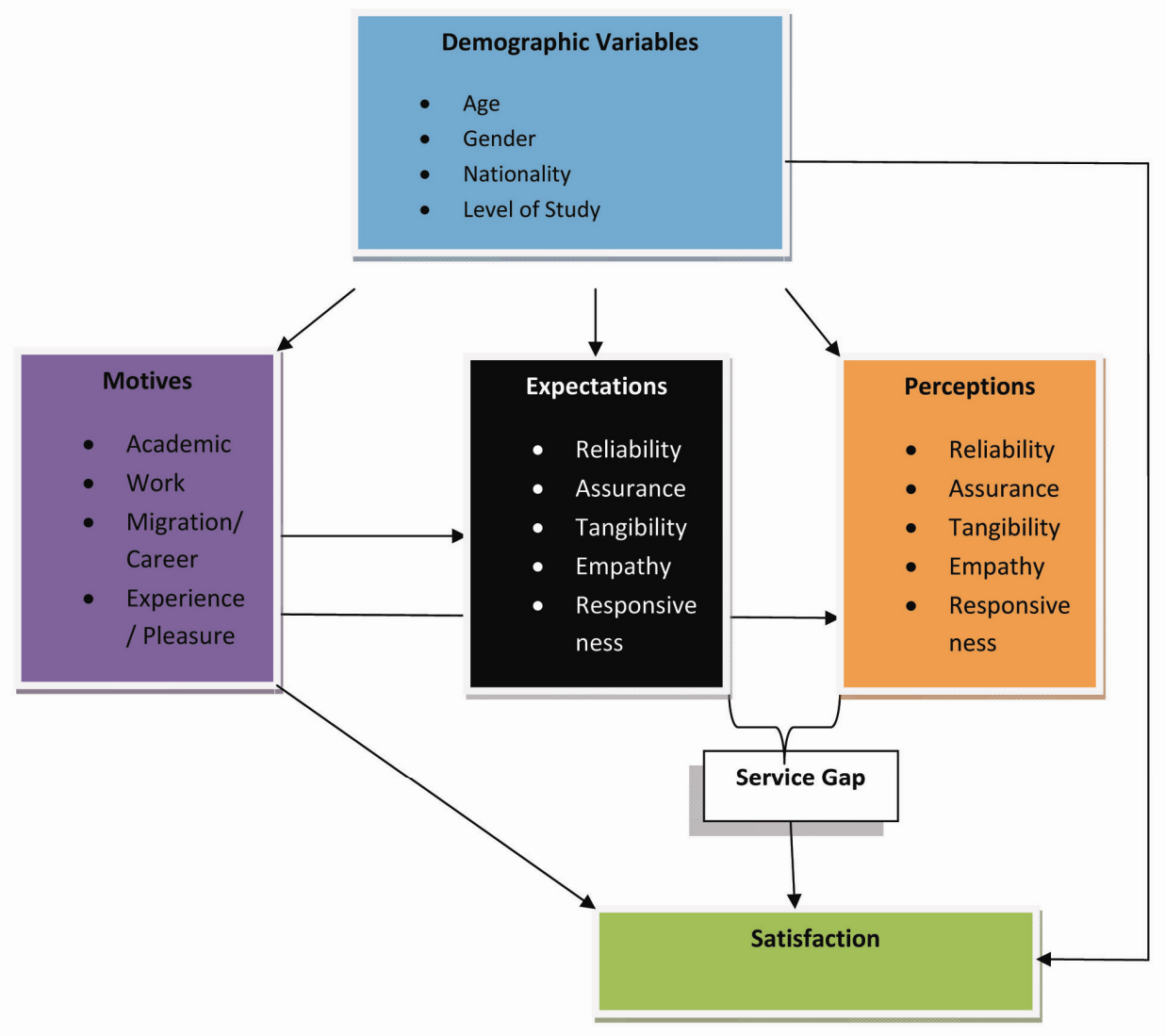

Figure 2. Conceptual framework of the service quality in higher education with demographic variables

\subsection{Empirical Data}

The survey of international students was carried out in April, 2012 with sample size of 263. The dataset of this survey was shared with the research carried out by Min et al. (2012). The survey was conducted in a private higher education institution in Singapore where international students pursued their courses in business administration. The samples were selected conveniently using the researchers' judgment. All the students were full-time students attending courses at different levels, ranging from diploma to Master degree.

A survey questionnaire was used and self-administered. The respondents were requested to answer the questionnaire and to return to the researcher immediately after completion. The survey questionnaire consisted of five major parts: motivation questions, expectation questions, perception questions, satisfaction questions, and demographics. To measure and develop the constructs, multiple statements were used and the responses to each statement were to be given on a 5-point Likert scale. The development and the validity test of the constructs were undertaken with the help of factor analysis.

\subsection{Data Analysis}

Firstly, the demographic profile of the respondents is described. After that the reliability and validity of the results are tested, using Cronbach's Alpha for reliability test and factor analysis for the construct validity. Then, the descriptive results of the survey are viewed and interpreted.

The major part of the data analysis is concerned with testing the relationship among the components of service quality framework, including demographic factor as shown in Figure 2. The conceptual framework shown in Figure 2 is now transformed into an empirical, analytical model of SEM type as shown in Figure 3. The SEM attempts to find the relationships among four key variables: motives, expectation, perception and satisfaction which are measured in aggregate value by averaging the scores of sub-dimensions of each of them. Moreover, the model does not include the service quality (gap), since its two determinants have been included. 


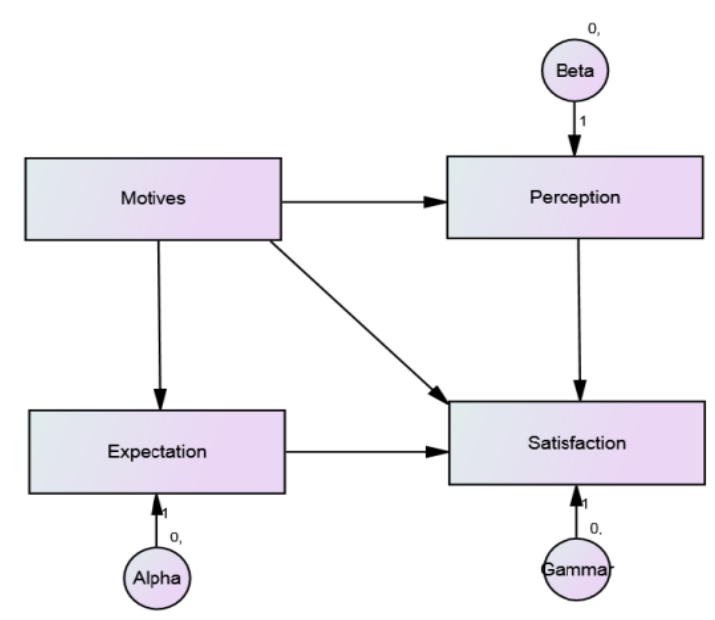

Figure 3. SEM for the relationships among level of motives, expectation, perception and satisfaction

The regression coefficients in the SEM shown in Figure 2 are estimated using IBM SPSS AMOS 6.0 software and the Maximum Likelihood method.

In the estimation, firstly the overall estimation (i.e., without grouping) was undertaken in order to find the relationships between the elements in the conceptual framework. Then, individual demographic variables were used for the grouping and the simultaneous analysis of groups of each demographic factor was undertaken in order to estimate parameters of the relationships as well as to test the differences between or among the groups. For testing the differences of groups, the Chi-square test is used. The comparison of results between or among groups leads to the judgment of the role of demographic factors in the service quality process. If there are significant differences in estimated parameter values of groups, it leads to a conclusion regarding the moderating effect of the demographic variable.

\section{Results}

\subsection{Profile of Respondents}

Demographics of respondents are summarized in the following Table 2. (Note: The total number varies from each other because of the missing data.)

Table 2. Profile of respondents

\begin{tabular}{lll}
\hline Variables & Frequency & Percentage \\
\hline Gender & 121 & 48.2 \\
Male & 130 & 51.8 \\
Female & 251 & 100 \\
Total & & \\
Age & 51 & 20.7 \\
Below 20 & 165 & 66.8 \\
$20-24$ & 30 & 12.46 \\
$25-29$ & 1 & 0.04 \\
30 and above & 247 & 100 \\
Total & & \\
Nationalities & 62 & 23.6 \\
Chinese & 60 & 22.8 \\
Indian & 41 & 15.6 \\
Indonesian & 24 & 9.1 \\
Vietnamese & 14 & 5.3 \\
Malaysian & 62 & 23.6 \\
Others & 263 & 100 \\
Total & & \\
\hline
\end{tabular}




\begin{tabular}{lll}
\hline Present Level of Study & & \\
Diploma & 84 & 33.3 \\
Bachelor & 74 & 29.4 \\
Master & 94 & 37.3 \\
Total & 252 & 100 \\
\hline
\end{tabular}

The samples can be seen as good representation of the population, as the data in Table 2 show a good coverage in terms of categories and the respondent numbers of each category. The samples consist of both types of gender, all age groups and various nationalities. It can be seen from the table that Chinese, Indian, Indonesian, Vietnam and Malaysian are the largest groups of nationalities and there are also many other nationalities from different continents (America, Europe, Africa and Asia). The samples are spread well across three levels of study.

\subsection{Reliability of Data}

The survey question uses the 5-point Likert scale in the measurements. The reliability of the data is checked with the reliability test using the Cronbach's Alpha value.

Firstly, the Cronbach's Alpha is found to be 0.7255 for the statements concerned with the 'motives of study' as listed in Table 3. This has a refined set of statements concerned with the 'motives of study', different from the original questionnaire. Those motives which could not be fitted in the specified four factors are dropped from further analysis. The motives are grouped into four factors using factor analysis. The factors' loading values are also shown in the Table 3.

Table 3. Reliability and validity of measurement scale (motives)

\begin{tabular}{llll}
\hline No. & Motive & Cronbach's Alpha $=0.7255$ & $\begin{array}{c}\text { Factor Loading } \\
(\text { KMO }=0.745)\end{array}$ \\
\hline 1 & Academic \& Education Quality & 0.7422 & \\
2 & Work & 0.5706 & \\
3 & Career \& Migration & 0.6136 & \\
4 & Pleasure \& Experience & 0.4560 & \\
\hline
\end{tabular}

Like for motives, the reliability and validity of data for Section B (Expectation) and Section C (Actual Experience or Perception) and Section D (Satisfaction) in the questionnaire are tested and shown in the following tables, Table 4 , Table 5 and Table 6 . The validity of the measurement on the service quality is checked with the help of the factor analysis and its factor loading values. Those statements which could not be fitted into their original factor categories are eliminated from the list.

Table 4. Reliability and validity test of measurement scale (expectations)

\begin{tabular}{llll}
\hline No. & Dimensions & Cronbach's Alpha $=0.9243$ & $\begin{array}{l}\text { Factor Loading } \\
(\mathrm{KMO}=0.897)\end{array}$ \\
\hline 1 & Responsiveness & 0.8618 & \\
2 & Assurance & 0.8129 & \\
3 & Empathy & 0.7951 & \\
4 & Tangibles & 0.8300 & \\
5 & Reliability & 0.9092 & \\
\hline
\end{tabular}

Table 5. Reliability and validity test of measurement scale (actual experience/perception)

\begin{tabular}{llll}
\hline No. & Dimensions & Cronbach's Alpha $=0.9293$ & $\begin{array}{c}\text { Factor Loading } \\
(\mathrm{KMO}=0.905)\end{array}$ \\
\hline 1 & Responsiveness & 0.8324 & \\
2 & Assurance & 0.8162 & \\
3 & Empathy & 0.7405 & \\
4 & Tangibles & 0.7779 & \\
5 & Reliability & 0.8894 & \\
\hline
\end{tabular}


Table 6. Reliability and validity test of measurement scale (satisfaction)

\begin{tabular}{llll}
\hline No. & Statements & $\begin{array}{l}\text { Cronbach's Alpha }= \\
0.8649\end{array}$ & $\begin{array}{l}\text { Factor Loading } \\
\text { (KMO=0.771) }\end{array}$ \\
\hline & Overall & 0.8649 & .770 \\
1 & I think I made the right decision to study in Singapore. & & .883 \\
2 & I think I made the right choice to study in this school. & .761 \\
3. & I will recommend Singapore as study destination to my friends. & & .871 \\
4. & I will recommend MDIS to my friends as the place to study & & .746 \\
5 & I will continue to keep in touch with MDIS after my studies. & & \\
\hline
\end{tabular}

\subsection{Descriptive Statistics}

The responses given by the samples are summarized in the following tables. Table 7 shows the means of four motives; academic and education, work, career and migration, and pleasure and experience. Among them, the highest motives are "Career" and "Migration", and the second highest motive is "Academic Education". The "Pleasure and "Experiential" motive is the third highest motive, followed by "Work".

Table 7. Motivations (means \& standard deviation)

\begin{tabular}{llll}
\hline No. & Type & Mean & Standard Deviation \\
\hline 1 & Academic \& Education & 3.9272 & .63154 \\
2 & Work & 3.1314 & .79423 \\
3 & Career \& Migration & 3.9302 & .71628 \\
4 & Pleasure \& Experience & 3.4277 & .64637 \\
& Overall & 3.6125 & .46973 \\
\hline
\end{tabular}

The motives vary with the demographic factors, as shown in Table 8. It can be seen that gender does not affect significantly on the motives. Among the nationalities, Indians have the highest motive in Academic and Education as well as Career and Migration. The Malaysian and Chinese have relatively high motive of working in Singapore. The students studying at the Master's level show the highest motives, especially in Academic/Education, and Career and Migration.

Table 8 . Motives by demographic variables

\begin{tabular}{|c|c|c|c|c|c|}
\hline & \multicolumn{5}{|l|}{ Motives } \\
\hline & Academic/Education & Work & $\begin{array}{l}\text { Career / } \\
\text { Migration }\end{array}$ & Pleasure/Experience & Total \\
\hline All Respondents & 3.93 & 3.13 & 3.93 & 3.43 & 3.61 \\
\hline \multicolumn{6}{|l|}{ Gender } \\
\hline Male & 3.97 & 3.19 & 3.91 & 3.45 & 3.63 \\
\hline Female & 3.90 & 3.09 & 3.96 & 3.47 & 3.60 \\
\hline \multicolumn{6}{|l|}{ Age } \\
\hline Below 20 & 3.92 & 2.98 & 3.92 & 3.35 & 3.54 \\
\hline $20-24$ & 3.95 & 3.17 & 3.94 & 3.45 & 3.62 \\
\hline $25-29$ & 3.91 & 3.20 & 3.98 & 3.43 & 3.63 \\
\hline 30 and above & 4.00 & 4.13 & 4.50 & 4.00 & 4.15 \\
\hline \multicolumn{6}{|l|}{ Nationality } \\
\hline Chinese & 3.80 & 3.34 & 3.90 & 3.41 & 3.61 \\
\hline Indian & 4.14 & 3.14 & 4.19 & 3.50 & 3.74 \\
\hline Indonesian & 4.03 & 3.00 & 3.99 & 3.38 & 3.6 \\
\hline Vietnamese & 3.81 & 3.27 & 3.92 & 3.29 & 3.57 \\
\hline Malaysian & 3.95 & 3.35 & 3.91 & 3.23 & 3.61 \\
\hline Others & 3.65 & 2.82 & 3.62 & 3.75 & 3.46 \\
\hline \multirow{2}{*}{\multicolumn{6}{|c|}{$\begin{array}{l}\text { Current Level of } \\
\text { Study }\end{array}$}} \\
\hline & & & & & \\
\hline Diploma & 3.97 & 3.08 & 3.91 & 3.45 & 3.60 \\
\hline Bachelor & 3.79 & 3.26 & 3.82 & 3.34 & 3.55 \\
\hline Master & 4.01 & 3.10 & 4.05 & 3.49 & 3.66 \\
\hline
\end{tabular}


The respondents' responses to expectation, perception and satisfaction levels can be summarized together with demographic variables as follows:

Table 9. Expectation, perception and satisfaction by demographic variable

\begin{tabular}{llll}
\hline & Expectation & Perception & Satisfaction \\
\hline All Respondents & 3.85 & 3.27 & 3.3 \\
Gender & & & \\
Male & 3.85 & 3.30 & 3.46 \\
Female & 3.86 & 3.20 & 3.20 \\
Age & & & \\
Below 20 & 3.84 & 3.14 & 3.39 \\
$20-24$ & 3.88 & 3.27 & 3.30 \\
$25-29$ & 3.81 & 3.31 & 3.49 \\
30 and above & NA. & 3.67 & 2.30 \\
Nationality & & & \\
Chinese & 3.67 & 3.28 & 3.34 \\
Indian & 4.18 & 3.59 & 3.56 \\
Indonesian & 3.96 & 3.12 & 3.28 \\
Vietnamese & 3.68 & 3.06 & 3.09 \\
Malaysian & 3.41 & 3.02 & 3.25 \\
Others & 3.95 & 2.88 & 3.11 \\
Current Level of Study & & & 3.39 \\
Diploma & 3.85 & 3.18 & 3.14 \\
Bachelor & 3.72 & 3.18 & 3.43 \\
Master & 4.04 & 3.35 & \\
\hline
\end{tabular}

Table 9 shows that the highest expectations are held by Indian students and Master's level students. In terms of perceived service quality, the older age (30 and above), Indian nationality and higher level study (Master's) are at relatively high levels. In the satisfaction level, the female group and older age (30 and above), Vietnamese and other nationalities and Bachelor's level students are found as having relatively high satisfaction levels. Thus, in general, the satisfaction level differs among the demographic groups.

\subsection{Empirical Results of SEM}

The overall (without grouping) results of SEM estimates are shown in Figure 4 and Table 10.

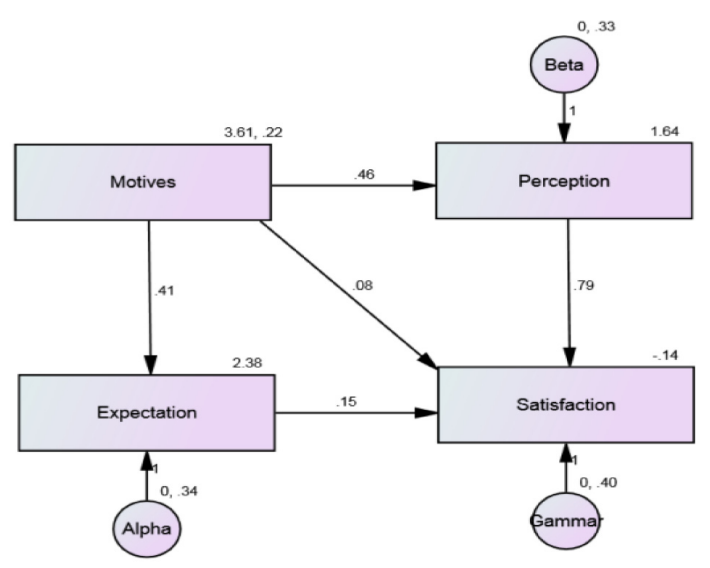

Chi-square $=13.590(1 \mathrm{df})$

$\mathrm{p}=.000$

Figure 4. Results of SEM 
Table 10. Overall regression weights of service quality components

\begin{tabular}{llllll}
\hline $\begin{array}{l}\text { Demographic } \\
\text { Factor }\end{array}$ & $\begin{array}{l}\text { Motivation } \\
\rightarrow \text { Expectation }\end{array}$ & $\begin{array}{l}\text { Motivation } \\
\rightarrow \text { Perception }\end{array}$ & $\begin{array}{l}\text { Motivation } \\
\rightarrow \text { Satisfaction }\end{array}$ & $\begin{array}{l}\text { Expectation } \\
\rightarrow \text { Satisfaction }\end{array}$ & $\begin{array}{l}\text { Perception } \\
\rightarrow \text { Satisfaction }\end{array}$ \\
\hline Overall & $.407 * * *$ & $.456 * * *$ & .081 & .145 & $.794 * * *$ \\
\hline$* * * \mathrm{p}=.000$. & & & &
\end{tabular}

The SEM model has been empirically tested and the results show that the relationship between motivation and expectation, the relationship between motives and perception are significant with the regressions weights, .407 and .456 respectively. Thus, the level of motives has a stronger influence on perception than on expectation. However, motives are not significantly related to satisfaction. Similarly, expectation does not relate significantly to satisfaction.

On the other hand, the relationship between perception and satisfaction is strong $(0.794)$ and significant at $100 \%$ confidence level. Nevertheless, the relationship between motives and satisfaction is weak (.081) and insignificant Thus, the role of motives (of study) is found more in the expectation and perception of service quality than the overall satisfaction of the service provided. The more crucial element of satisfaction is found to be perception (actual service quality experience).

Table 11. Estimates of service quality variables

\begin{tabular}{lllll}
\hline Variables & & Estimate & Std. Error & p-value \\
\hline Motives & Mean & 3.610 & .030 & $* * *$ \\
Expectation & Intercept & 2.383 & .373 & $* * *$ \\
Perception & Intercept & 1.644 &, 357 & $* * *$ \\
Satisfaction & Intercept & -.143 & .436 & \\
\hline
\end{tabular}

*** Significant at .000 .

The fit of the model is tested with Chi-square statistics; the Chi-square value is 13.590 and the degree of freedom is 1 , being significant at $\mathrm{p}$-value .000 . That means, the model has produced significant estimates overall. Specifically, the mean value of Motives and the intercept of Expectation and Perception are significant at p-value .000. However, the model is unable to provide a significant estimate of the intercept of Satisfaction.

Table 12. Regression weights between service quality variables by demographic factors

\begin{tabular}{|c|c|c|c|c|c|}
\hline $\begin{array}{l}\text { Demographic } \\
\text { Factor }\end{array}$ & $\begin{array}{l}\text { Motivation } \\
\rightarrow \text { Expectation }\end{array}$ & $\begin{array}{l}\text { Motivation } \\
\rightarrow \text { Perception }\end{array}$ & $\begin{array}{l}\text { Motivation } \\
\rightarrow \text { Satisfaction }\end{array}$ & $\begin{array}{l}\text { Expectation } \\
\rightarrow \text { Satisfaction }\end{array}$ & $\begin{array}{l}\text { Perception } \\
\rightarrow \text { Satisfaction }\end{array}$ \\
\hline \multicolumn{6}{|l|}{ Gender } \\
\hline Male & $.485 * * *$ & $.630 * * *$ & .122 & .109 & $.773^{* * *}$ \\
\hline Female & $.363^{* *}$ & $.272 * *$ & .022 & .194 & $.730^{* * *}$ \\
\hline \multicolumn{6}{|l|}{ Age } \\
\hline$<20$ & $.485 * * *$ & $.630 * * *$ & .122 & .109 & $.773^{* * * *}$ \\
\hline $20-24$ & $.419 * * *$ & $.404 * * *$ & $.285^{* *}$ & .071 & $.860^{* * *}$ \\
\hline $25-29$ & .175 & $.461^{*}$ & $-.435^{*}$ & $.610^{* * *}$ & .118 \\
\hline \multicolumn{6}{|l|}{ Nationality } \\
\hline Chinese & $.844 * *$ & $.548 * *$ & -.093 & $.511^{* * *}$ & $.371^{*}$ \\
\hline Indian & $.462 * *$ & .323 & $.530 * *$ & $-.873 * * *$ & $.911^{* * *}$ \\
\hline Indonesian & -.016 & $.514 * *$ & .273 & .288 & $.718^{* * *}$ \\
\hline Vietnamese & $.490^{*}$ & .218 & .313 & -.437 & $1.097 * * *$ \\
\hline Malaysian & -.025 & $.836^{* *}$ & .459 & -.128 & -.308 \\
\hline Others & .325 & .365 & -.327 & .217 & $1.169^{* * *}$ \\
\hline \multicolumn{6}{|c|}{$\begin{array}{l}\text { Present Level of } \\
\text { Study }\end{array}$} \\
\hline Diploma & .190 & $.587 * *$ & .230 & $.295^{*}$ & $.757^{* * *}$ \\
\hline Bachelor &. $.416^{* *}$ & $.371 * *$ & .034 & .144 & $.673^{* * *}$ \\
\hline Master & $.450 * *$ & $.388 *$ & .020 & .049 & $.846^{* * *}$ \\
\hline
\end{tabular}

$* * * \mathrm{p}=.000,{ }^{* *} \mathrm{p}<.05, * \mathrm{p}<.1$. 
When the SEM is analysed using groups of each demographic variable, the results of estimates are as shown in the Table 12. The findings from this demographic analysis are, firstly, the existence of the relationship between motives and satisfaction, particularly in the age variable. Of the two age groups, the age group 20-24 shows a positive relationship with the regression weight .285, whereas the age group 25-29 shows a negative weight of -.435 , but being significant only at $90 \%$ confidence level. So, it is likely that students of the older age groups are less satisfied with the education services provided when they have higher level of motives of study. In contrast, the younger age group is likely to be satisfied with the education services provided, when they have a higher level of motives of study. Similar relationship is also found in the group of Indian students who are more satisfied with the education services provided, when they hold high level of motives of study.

Another important finding is that the overall pattern of relationships between service quality variables remains unchanged from the overall picture we discovered earlier. However, the magnitudes of relationships are different among the groups of demographic variables. Firstly, concerning gender, the male group has more regression weights than the female group in most types of relationships. Groups of age and level of study also generally show some variations in the weights of relationships. The most apparent differences in the weights of relationships are found in the nationality groups. For instance, Chinese students show a strong relationship in terms of motivation and expectation (.844) while Indian students have only relatively moderate relationship (.462). Contrary to this, Indian students show high relationship between perception and satisfaction (.911), while in the case of Chinese students, the weight of relationship is only at relatively low magnitude (.371). This means that Indian students are determining the level of satisfaction mainly based on the perceived service quality, whereas Chinese students' satisfaction level is not determined solely by the perceived quality. The heaviest weight on this relationship is found in the other nationality groups which rate high satisfaction level when they perceive the service quality as high.

The findings discussed above lead us to conclude that demographic factors are important in the evaluation of service quality. Students do evaluate the components of service quality, namely motives of study, expectation, perception and satisfaction, differently, depending on their demographics. So, it is necessary to treat demographic variables as a moderating factor in the process of service quality evaluation.

\subsection{Test Results of Hypotheses}

The outputs of Amos 6 for the simultaneous analysis of individual demographic factors show the Chi-square statistics of differences among demographic groups. The following table summarizes the results of each analysis indicating the hypothesis concerned.

Table 13. Chi-Square test results of individual demographic factor, group analysis

\begin{tabular}{llllll}
\hline Hypothesis & Demographic Factor & $\begin{array}{l}\text { Chi-Square } \\
(\mathrm{CMIN})\end{array}$ & $\begin{array}{l}\text { Degree of Freedom } \\
(\mathrm{df})\end{array}$ & P-Value & Decision \\
\hline 1 & Gender & 15.468 & 2 & .000 & Reject $\mathrm{H}_{\mathrm{o}}$ \\
2 & Age & 19.710 & 3 & .000 & Reject $\mathrm{H}_{\mathrm{o}}$ \\
3 & Nationality & 21.868 & 6 & .001 & Reject $\mathrm{H}_{\mathrm{o}}$ \\
4 & Present Level of Study & 26.471 & 3 & .000 & Reject $\mathrm{H}_{\mathrm{o}}$ \\
\hline$* * * \mathrm{p}=.000, * * \mathrm{p}<.05 * \mathrm{p}<.10$. & & & &
\end{tabular}

The results show that all the null hypotheses cannot be accepted as the probability of obtaining the test statistics while there is no significant difference between or among groups in the population is less than $5 \%$. So, all the null hypotheses are rejected and the alternative hypotheses are accepted. The conclusion of the test of hypotheses is hence the significant influence of demographic factors in the evaluation of service quality. In other words, the demographic factors of international students can play a moderating role in evaluating the service quality and satisfaction in higher education.

\section{Discussion}

Services delivered to customers and clients are necessary to be evaluated from their perspectives, rather than from the firm's own perspective. Service quality is an important element in every service marketing programme. Particularly, education services are required to evaluate their educational services' quality from the students' perspective. This study has investigated the service quality of a private higher education institution evaluated by international students. The structural equation model (SEM) was estimated and the results showed that the 
motivation has moderate relationships with expectation and perception, but the relationship with overall satisfaction was found to be insignificant. However, the relationship between perception and satisfaction was found as strong and significant.

The findings of simultaneous group analysis showed that the demographic factor is generally important in the relationships among the elements of service quality. Among four demographic variables, nationality and gender were found as crucial variables in the evaluation of education services. Different nationalities and genders cause different magnitudes of regression weights in the relationships among components of service quality.

As a result of the critical role of demography in the service quality evaluation, higher education institutions should consider the design and delivery of their services in accordance with the demographic characteristics of their target students. The organisation of services and actual practices of service delivery should focus on the needs of particular demographic groups of students. Market segmentation based on the demographic variable is highly appropriate and international students should be served according to the demographic-based segments. The view of homogeneity among international students should be avoided, although there might be increasing trend of similarities due to increasing globalization and changing international environment. Specifically targeting and differentiating to different segments of international students can be helpful to higher education institutions to effectively attract international students and to raise the level of satisfaction ultimately.

\section{References}

Adee, A. (1997). Linking student satisfaction and service quality perceptions: the case of university education. European Journal of Marketing, 37(7), 528-535. Retrieved from http://web.uct.ac.za/staff/jbeneke/justin/p528.pdf

Al-Khali, A., \& Mahmoud, A. B. (2012). The Role of Demographics in Patients' Perceptions towards the Quality of Health Care Services Provided at Public Hospitals in Damascus. European Journal of Economics, Finance and Administrative Services, 48, 113-121. Retrieved from

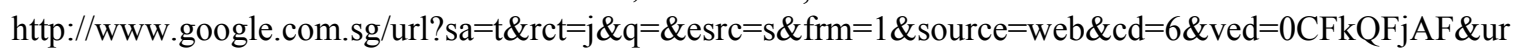
l=http\%3A\%2F\%2Fwww.researchgate.net\%2Fpublication\%2F226123628_The_Role_of_Demographics_in _Patients'_Perceptions_towards_the_Quality_of_Health_Care_Services_Provided_at_Public_Hospitals_in

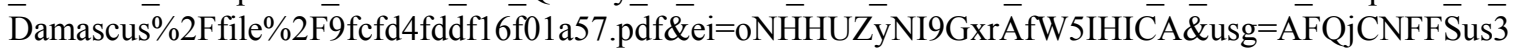
3juEeyr2J-3cefb3-Lz60Q\&sig2=yyN2margAwH8U9luvICwdw

Arambewela, R., \& Hall, J. (2006). A Comparative Analysis of International Education Satisfaction using SERVQUAL. Journal of Services Research, 6, Special Issue (July), 142-163. Retrieved from http://dro.deakin.edu.au/eserv/DU:30003511/arambewela-comparativeanalysisof-2006.pdf

Barnes, B. R. (2007). Analyzing Service Quality: The Case of Post-graduate Chinese Students. Total Quality Management, 18(3), 313-331. http://dx.doi.org/10.1080\%2F14783360601152558

Buttle, F. (1996). SERVQUAL: Review, Critique, Research Agenda. European Journal of Marketing, 30(10), 8-32. http://dx.doi.org/10.1108/03090569610105762

Chih, W-H., Tang, T-W., \& Chen, I-J. (n.d.). The Service Quality Perceptual Analysis of Mobile Phone Uses in Mainland China. Retrieved from http://www1.rdoffice.ndhu.edu.tw/exchange/abroad/abroad93/TZW-paper.pdf

Gagliano, K. B., \& Hathcote, J. (1994). Customer Expectations and Perceptions of Service Quality in Retail Apparel Specialty Stores. Journal of Services Marketing, 9(1), 60-69. http://dx.doi.org/10.1108/08876049410053311

Ganesan-Lim, C., Russell-Bennett, R., \& Dagger, T. (2008). The impact of service contact type and demographic characteristics on service quality perceptions. Journal of Services Marketing, 22(7), 550-561. http://dx.doi.org/10.1108/08876040810909677

Gupta, K. K., \& Bansal, J. (2011). Effect of Demographic Variables on Customer Perceived Internet Banking Service Quality. Paradigm, $X V(1 \& 2), 83-92$.

Ham, L., \& Hayduk, S. (2003). Gaining competitive advantages in higher education: analyzing the gap between expectations and perceptions of service quality. International Journal of Value-Based Management, 16(3), 223-242. http://dx.doi.org/10.1023/A:1025882025665

Ilias, A., Hasan, H. F. A., Rahman, R. A., \& Yasoa, M. R. B. (2008). Student Satisfaction and Service Quality-Any Differences in Demographic Factors? International Business Research, 1(4), 131-143. Retrieved from http://ccsenet.org/journal/index.php/ibr/article/view/819/809 
Jusoh, A., Omain, S., Majid, N. A., Som, H. M., \& Shamsuddin, A. S. (2004). Service Quality in Higher Education: Management Students' Perspective. Research Management Centre, University of Technology, Malaysia. Retrieved from http://eprints.utm.my/3763/1/AHMADJUSOH71982.pdf

Min, S., Khoon, C. C., \& Tan, B. L. (2012). Motives, Expectations, Perceptions and Satisfaction of International Students pursuing Higher Education in Singapore. International Journal of Marketing Studies, 4(6), 122-138. http://dx.doi.org/10.5539/ijms.v4n6p122

Palli, J. G., \& Mamilla, R. (2012). Students' Opinions of Service Quality in the Field of Higher Education. Creative Education, 3(4), 430-438. http://dx.doi.org/10.4236/ce.2012.34067

Parasuraman, A., Zeithaml, V. A., \& Berry, L. L. (1985). A Conceptual Model of Service Quality and its Implications for future research. Journal of Marketing, 49, 41-50. http://dx.doi.org/10.2307/1251430

Parasuraman, A., Zeithaml, V. A., \& Berry, L. L. (1988). SERVQUAL: A Multiple Item Scale for measuring Service Quality. Journal of Retailing, 64(1), 12-40. Retrieved from http://areas.kenanflagler.unc.edu/Marketing/FacultyStaff/zeithaml/Selected\%20Publications/SERVQUAL\% $20 \mathrm{~A} \% 20$ MultipleItem $\% 20$ Scale $\% 20$ for $\% 20$ Measuring $\% 20$ Consumer $\% 20$ Perceptions $\% 20$ of $\% 20$ Service $\% 2$ 0Quality.pdf

Parasuraman, A., Berry, L. L., \& Zeithaml, V. (1991). Understanding of Customer Expectations of Service. Sloan Management Review, Spring, 39-48.

Ramez, W. S. (2011). Customers' Socio-economic Characteristics and The Perception of Service Quality of Bahrain's Commercial Banks. International Journal of Business and Management, 6(8), 113-126.

Schiffman, L. G., \& Kanauk, L. L. (2007). Consumer Behavior (9th ed.). Prentice-Hall: NJ.

Schwantz, G. D. (1996). Service Quality in Higher Education Expectations and Perceptions of Traditional and Non-traditional Students. Ph. D. Dissertation, Texas Technical University. Retrieved from https://repositories.tdl.org/ttu-ir/bitstream/handle/2346/12914/31295010497773.pdf?sequence=1

Tsinidou, M., Gerogiannis, V., \& Fitsilis, P. (2010). Evaluation of the factors that determine quality in higher education: An empirical study. Quality Assurance in Education, 18(1), 227-244. http://dx.doi.org/10.1108/09684881011058669

\section{Copyrights}

Copyright for this article is retained by the author(s), with first publication rights granted to the journal.

This is an open-access article distributed under the terms and conditions of the Creative Commons Attribution license (http://creativecommons.org/licenses/by/3.0/). 